\title{
KARAKTERISTIK MANTAN BURUH MIGRAN INDONESIA PENERIMA DANA CSR PERBANKAN DI KECAMATAN DONOMULYO KABUPATEN MALANG
}

\author{
Sri Wahjuni Latifah \\ Fakultas Ekonomi dan Bisnis Universitas Muhammadiyah Malang \\ E-mail: yuni.latifah14@gmail.com
}

\begin{abstract}
Research on the characteristics of Indonesian Migrant Workers Former grantees Banking CSR is done in District Donomulyo Malang. The purpose of this study is to provide empirical evidence about the characteristics of former migrant workers so as to be considered the government to improve their welfare. Quota sampling techniques obtained 45 respondents. Data analysis with quantitative and qualitative approaches. The results of this study indicate that migrant workers productive age (35.28 years) with an average experience of 5.8 years. The level of high school education. His favorite of Taiwan. Investment enough value the average Rp.108.000.000.
\end{abstract}

Keywords: Indonesian Migrant Workers, Banking CSR, Welfare

\begin{abstract}
Abstrak
Penelitian tentang karakteristik Buruh Migran Indonesia Mantan penerima CSR Perbankan dilakukan di Kecamatan Donomulyo Malang. Tujuan dari penelitian ini adalah untuk memberikan bukti empiris tentang karakteristik mantan buruh migran sehingga dianggap pemerintah untuk meningkatkan kesejahteraan mereka. Teknik pengambilan sampel kuota yang diperoleh 45 responden. Analisa data dengan pendekatan kuantitatif dan kualitatif. Hasil penelitian ini menunjukkan bahwa buruh migran usia produktif $(35,28$ tahun) dengan pengalaman rata-rata 5,8 tahun. Tingkat pendidikan SMA. Favoritnya Taiwan. Invetasi nilai yang cukup dalam rata-rata Rp.108.000.000.
\end{abstract}

Kata kunci: Buruh Migran Indonesia, Perbankan CSR, Kesejahteraan

Fenomena global yang terjadi pada sebagian negara di dunia adalah migrasi internasional, termasuk migrasi tenaga kerja (Diyanti, 2011). Meningkatnya hubungan antar negara pada akan berpengaruh pada migrasi ke negara yang bersangkutan. Akibatnya terjadi pergerakan modal termasuk mobilitas sumber daya manusia.

Meningkatnya jumlah pekerja migran dari tahun-tahun untuk bekerja di luar negeri merupakan salah satu indikator dari globalisasi. Istilah TKI (tenaga kerja Indonesia) sudah mulai beralih dengan istilah Buruh
Migran. Indonesia sebagai bagian integral dari ekonomi global tidak dapat melepaskan diri dari dinamikatersebut. Dalamperkembangannya, negara-negara tujuan TKI semakin bertambah (Diyanti, 2011). Negara-negara tujuan tersebut antara lain: Malaysia, Taiwan, Singapura, Brunei, Korea, Saudi Arabia Sebagai akibatnya, pengiriman pekerja migran ke luar negeriberdampak signifikan pada makro ekonomi (PDRB). Rata-rata TKI mengirimkan uang US $\$ 500$ juta atau sekitar Rp. 4,5 triliun per bulan ke Tanah Air. Pengiriman devisa ke dalam negeri (remitansi) 
Ekonomika-Bisnis Vol. 4 No.1 Bulan Januari Tahun 2013. Hal 85-94

tersebut dinilai paling efisien diabnding devisa lain, karena tidak membutuhkan modal terlalu besar (Handayani, 2012).

Hingga tahun 2012, jumlah TKI yang bekerja di luar negeri telah mencapai 3.998.592 orang.data ini yang dikeluarkan oleh Badan Nasional Penempatan dan Perlindungan TKI (BNP2TKI) yang tentu saja tidak mencakup mereka yang bekerja di luar negeri tanpa jalur resmi. Jumlah TKI ilegal cukup besar (khususnya di Malaysia). Jumlah TKI ilegal di Malaysia diperkirakan dua per tiga dari total pekerja migran asal Indonesia (Sukamdi, 2008).

Demikian juga para buruh migran Indonesia yang bekerja di luar negeri yang berasal dari Daerah Malang Raya cukup besar. Namun masalah yang terjadi adalah saat mereka sudah pulang kembali ke Indonesia yang dalam penelitian ini disebut sebagai istilah Mantan Buruh Migran Indonesia (MBMI), mereka banyak yang menjadi pengangguran dan tidak produktif. Hal ini yang ditangkap oleh beberapa Perbankan di Jawa Timur seperti Bank Jatim, dengan menggulirkan Dana CSR untuk mereka. Perbankan akan mendapatkan reputasi yang baik di mata masyarakat dan pemerintah, demikian juga mantan buruh migran Indonesia dapat menjadi produktif dari adanya dana tersebut. Namun setelah dana CSR digulirkan tidak ada tindak lanjut dari perbankan sehingga tidak dapat dikatakan apakah mereka semakin meningkat kesejahteraannya atau tidak.

Di sisi lain berdirinya sebuah perusahaan mewajibkan perusahaan memenuhi kewjiban sosialnya sesuai dengan Peraturan Pemerintah. Di Indonesia, pemerintah telah mengatur melalui UU No. 40/2007 tentang Peseroan Terbatas Bab V tentang Tanggung Jawab Sosial dan Lingkungan (CSR). Ebert
(2003) mendefinisikan corporate social responsibility (CSR) sebagai usaha perusahaan untuk menyeimbangkan komitmenkomitmennya terhadap kelompok-kelompok dan individual-individual dalam lingkungan perusahaan tersebut, termasuk pelanggan, perusahaan lain, karyawan dan investor. CSR memberikan perhatian terhadap lingkungan dan sosial ke dalam operasinya dan interaksinya dengan stakeholders yang melebihi tanggungjawab di bidang hukum (Darwin, 2004). Dalam kemajuan industri sekarang, tekanan masyarakat kepada perusahaan agar mereka melakukan pembenahan sistem operasi perusahaan menjadi sistem yang memiliki kepedulian dan tanggungjawab terhadap sosial sangat kuat, perkembangan tehnologi dan industri yang pesat dituntut meberikan kontribusi positif terhadap lingkungan sekitar.

Penerapan CSR dalam perusahaan diharapkan selain memiliki komitmen finansial kepada pemilik atau pemegang saham (shareholders), tapi juga memiliki komitmen sosial terhadap para pihak lain yang berkepentingan, karena CSR merupakan salah satu strategi bisnis perusahaan dalam jangka panjang. Adapun tujuan dari CSR adalah: (1) meningkatkan citra perusahaan dan mempertahankan, biasanya secara implisit asumsi bahwa perilaku perusahaan secara fundamental adalah baik, (2) membebaskan akuntabilitas organisasi atas dasar asumsi adanya kontrak sosial di antara organisasi dan masyarakat dan (3) sebagai penunjang dari pelaporan tradisional dan tujuannya adalah untuk memberikan infomasi kepada investor.

Pasca kepulangan buruh migran ke Tanah Air akan menyebabkan bertambahnya pengangguran jika buruh migran tersebut tidak menyiapkan skill dan usahanya. 
Faktanya adalah: hampir $70 \%$ buruh migran lulusan SD, bahkan ada kasus yang ditemukan buta huruf(Diyanti, 2011). Hal ini perlu dukungan berbagai pihak termasuk pemerintah setempat untuk melakukan pemberdyaan buruh migran pasca kepulangannya sebagai upaya untuk meningkatkan kesejahteraan dan meningkatkan nilai ekonomis. Salah satu hal yang bisa dilakukan adalah pemberdayaan mantan buruh migran tersebut. Pemberdayaan (empowering) adalah serangkaian kegiatan upaya umum untuk meningkatkan kemampuan dan memperluas akses terhadap perubahan serta mampu berperan dalam menentukan nasibnya sendiri, melalui penciptaan peluang yang seluas-luasnya agar mampu berpartisipasi (Sumodiningrat, 1997 dan 1999).

\section{Metode Penelitian}

Populasi penelitian ini adalah mantan buruh migran Indonesia di Kecamatan Donomulyo Kabupaten Malang. Sampel penelitian diambil dengan teknik Quota Sampling, yaitu berdasarkan jumlah pengiriman tenaga kerja yang paling banyak bersumber dari3 (tiga) desa yaitu Desa Donomulyo, Desa Sumberoto, dan Desa Purworejo Kecamatan Donomulyo Kabupaten Malang. Berdasarkan hal tersebut maka diperoleh 45 responden.

Variabel penelitian ini terdiri dari: a) Variabel Sosial yang meliputi: jenis kelamin, status perkawinan, umur, pendidikan, pengalaman kerja, keahlian, b) Variabel Budaya yang meliputi: lingkungan pembentuk, latar belakang keluarga, jumlah tanggungan, fasilitas, peran pemerintah setempat dan c) VariabelEkonomi yang meliputi iklim usaha, bantuan permodalan dan investasi. Variabel penelitian diukur dengan skala likert 4 skor.
Data penelitian dikumpulkan dengan berbagai metode yaitu: menyebar kuesioner kepada mantan buruh migran dan keluarganya. Berikutnya data diperoleh dengan melakukan wawancara dengan mereka, wawancara dengan lembaga dan pihak terkait seperti pemerintah daerah setempat.

Analisis data dilakukan dengan pendekatan kuantitatif dan kualitatif. Tahap pertama dilakukan uji validitas dan realibiltas data untuk selanjutnya melakukan pengujian statistik deskriptif, dan melakukan pemaknaan data penelitian. Tahap akhir dilakukan analisis dirkriptif kualitatif.

\section{Hasil Penelitian dan Pembahasan}

Wilayah Kecamatan Donomulyo mempunyai luas $19.259 \mathrm{Ha}$ atau $19259 \mathrm{Km}^{2}$ terdiri dari 10 Desa 39 Dusun dengan ketinggian kurang lebih $480 \mathrm{mDpl}$. Lebih jauh jika dilihat dari perspektif ekonomi mata pencaharian masyarakat Donomulyo sangat bervariasi mulai dari petani, peternak, wiraswasta, PNS dan pedagang. Tetapi mayoritas masyarakat Donomulyo menggantungkan diri dari hasil bertani, ini dilihat dari banyaknya prosentase warga yang bertani. Namun demikian Kecamatan Domomulyo adalah salah satu daerah yang mengirimkan Tenaga Kerja Indonesia ke Luar Negeri. Negara tujuan sangat beragam baik ke negara Arab maupun ke Asia sendiri.

Berdasarkan hasil uji realibitas dan validitas menunjukkan bahwa semua data adalah reliabel dan valid. Dengan demikian dapat dikatakan bahwa kuesioner ini layak menjadi alat ukur dalam pengukuran variabel penelitian ini.

Berdasarkan tabel 1 dapat diketahui bahwa TKI yang berasal dari Kecamatan Donomulyo berumur rata-rata 35,28 tahun. 
Ekonomika-Bisnis Vol. 4 No.1 Bulan Januari Tahun 2013. Hal 85-94

Hal ini indikator bahwa TKI tersebut memiliki usia yang cukup dan demikian berkaitan dengan memiliki pengalaman yang luas terlihat dari masa kerja yang rata-rata adalah 5,8 tahun. Masa kerja lebih 5 tahun juga merupakan indikator TKI tersebut mempunyai pengalaman yang baik dan cukup lama bekerja di Luar Negeri. Jika diamati lebih jauh ternyata TKI yang berasal dari Desa Purworejo dan Sumberoto memiliki pengalaman rata-rata 5 tahun sedangkan TKI dari Desa Donomulyo memiliki pengalaman kerja rata-rata 6,7 tahun
Jika diamati dari tingkat pendidikan maka TKI dari Kecamatan Donomulyo ini hampir semua memiliki pendidikan yang cukup yaitu tingkat SMA. Tingkat pendidikan SMA merupakan tingkat pendidikan yang cukup untuk mengasah kemapuan bidang lain yang diperlukan seperti Bahasa Asing maupun keahlian masing-masing.

Berdasarkan tabel 1 dapat dilihat bahwa TKI dari Kecamatan Donomulyo lebih banyak yang bekerja ke negara Taiwan, selanjutnya keHongkong, Korea Selatan dan Saudi Arabia. Dengan demikian

Tabel 1. Data Demografi Responden

\begin{tabular}{|c|c|c|c|c|c|c|}
\hline & & Umur & Pendidikan & Negara & Lama & Investasi \\
\hline \multirow[t]{2}{*}{$N$} & Valid & 45 & 45 & 45 & 45 & 45 \\
\hline & Missing & 0 & 0 & 0 & 0 & 0 \\
\hline \multicolumn{2}{|c|}{ Mean } & 35.2889 & 17.6444 & 2.1556 & 5.8222 & 108.5556 \\
\hline \multicolumn{2}{|c|}{ Mode } & $33.00^{\mathrm{a}}$ & 3.00 & 1.00 & 5.00 & 150.00 \\
\hline \multicolumn{2}{|c|}{ Std. Deviation } & 8.40893 & 17.92301 & 1.66454 & 3.43967 & 83.37772 \\
\hline
\end{tabular}

a. Multiple modes exist. The smallest value is shown

Tabel 2. Hubungan Umur dengan Negara Tujuan

\begin{tabular}{llllllll}
\hline Kategori & Taiwan & Korsel & Malaysia & Hongkong & $\begin{array}{c}\text { Arab } \\
\text { Saudi }\end{array}$ & Singapura & Thailand \\
\hline$<25$ th & 2 & & & & & & \\
25 th -14 & 2 & 2 & 6 & 1 & 1 & 1 \\
35 th & & & & & & & \\
36 th -7 & 2 & & 1 & 1 & & \\
46 th & & & 2 & & & \\
46 th -3 & & & & & &
\end{tabular}


negara tujuan TKI yang paling favorit adalah negara Taiwan. Namun jika diamati karakteristik dari desa masing-masing ternyata TKI yang berasal dari Desa Donomulyo paling banyak bekerja ke negara Hongkong, sedangkan TKI dari Desa Purworejo dan Sumberoto lebih banyak bekerja ke negara Taiwan.

Lebih jauh jika diamati hubungan antara umur dan negara tujuan, pendidikan dengan negara tujuan, negara tujuan dan investasi serta lama bekerja dengan investasi dapat dilihat pada tabel 2 .

Jika diamati dari hubungan umur TKI dengan Negara tempat bekerja maka dapat dikatakan bahwa TKI yang bekerja di Negara Taiwan sangat bervariasi usianya dari umur 23 tahun sampai 56 tahun. Secara umum usia TKI yang produktif, yaitu 25 tahun sampai 35 tahun akan diterima di setiap negara.

Jika dilihat dari hubungan tingkat pendidikan dengan negara tujuan maka secara umum dapat dikatakan bahwa negara Taiwan menerima TKI dengan tingkat pendidikan yang bervariasi baik SD, SMP atau SMA/SMK. Sedangkan negara lainnya yaitu Korsel, Malaysia, Hongkong, Arab Saudi, Singapura dan Thailand hampir semua berpendidikan SMA dan sederajat.

Negara yang bisa memberikan penghasilan tinggi adalah negara Korea Selatan. Hongkong dan Arab Saudi sehingga TKI yang bekerja dinegara tersebut memiliki nilai investasi yang tinggi pula yaitu lebih dari 250 (dua ratus lima puluh) juta rupiah.

Tabel 3. Hubungan Tingkat Pendidikan dengan Negara Tujuan

\begin{tabular}{llllllll}
\hline $\begin{array}{l}\text { Tingkat } \\
\text { pendidikan }\end{array}$ & $\begin{array}{l}\text { Taiwa } \\
\mathrm{n}\end{array}$ & $\begin{array}{l}\text { Korse } \\
\mathrm{l}\end{array}$ & $\begin{array}{l}\text { Malaysi } \\
\mathrm{a}\end{array}$ & $\begin{array}{l}\text { Hongkon } \\
\mathrm{g}\end{array}$ & $\begin{array}{l}\text { Arab } \\
\text { Saud } \\
\mathrm{i}\end{array}$ & $\begin{array}{l}\text { Singapur } \\
\mathrm{a}\end{array}$ & $\begin{array}{l}\text { Thailan } \\
\mathrm{d}\end{array}$ \\
\hline SD & 2 & & & 2 & & & \\
SMP & 4 & & & & 1 & & 1 \\
SMA/SM & 22 & 2 & 3 & 7 & 1 & 1 & 1 \\
$\mathrm{~K}$ & & & & & & & \\
\hline
\end{tabular}

Tabel 4. Hubungan Nilai Investasi dengan Negara Tujuan

\begin{tabular}{llllllll}
\hline $\begin{array}{l}\text { Nilai } \\
\text { investasi/neg }\end{array}$ & Taiwan & Korsel & Malaysia & Hongkong & $\begin{array}{l}\text { Arab } \\
\text { Saudi }\end{array}$ & $\begin{array}{l}\text { Singa } \\
\text { pura }\end{array}$ & Thailan \\
\hline$<50 \mathrm{Jt}$ & 4 & & 3 & & \\
$50 \mathrm{Jt}-<150$ & 13 & 2 & 3 & & & \\
$\mathrm{Jt}$ & & & & & & & \\
$150 \mathrm{jt}$ & -10 & 1 & 1 & 2 & 1 & 1 & 1 \\
$<250 \mathrm{Jt}$ & & & & & & & \\
$\geq 250 \mathrm{Jt}$ & & 1 & & 1 & 1 & \\
\hline
\end{tabular}


Ekonomika-Bisnis Vol. 4 No.1 Bulan Januari Tahun 2013. Hal 85-94

Sedangkan negara Taiwan meskipun menjadi negara favorit tetapi memberikan penghasilan yang lebih rendah dibanding Korsel, Hongkong, dan Arab Saudi. Investasi TKI tersebut berupa rumah, tanah, kendaraan, toko, warung makan, minimarket, dan salon.

Lama bekerja belum tentu memiliki nilai investasi yang besar. Hal ini dapat dilihat dari tabel di atas bahwa TKI yang pengalaman bekerjanya antara 5 tahun sampai 10 tahun memiliki nilai investasi yang cukup besar yaitu dari 50 juta rupiah sampai lebih 250 juta rupiah. Namun TKI yang pengalaman kerjanya lebih 10 tahun bisa juga hanya memiliki investasi kurang dari 250 juta rupiah. Berikut adalah Karakteristik TKI berdasarkan Aspek Sosial, Budaya dan Ekonomi.
Berdasarkan tabel 6 dapat dikatakan bahwa TKI Kecamatan Donomulyo mempunyai tingkat sosial yang tinggi. Hal ini dapat diukur dari tingkat/rasa aman di daerah tersebut, selalu dilibatkan dalam pengambilan keputusan publik pada daerah setempat, mendapatkan pelayanan kesehatan dan menerima bantuan sosial yang cukup dari pemerintah atau instansi lain. Mereka juga dapat melakukan pemberian bantuan sosial seperti infaq, sodaqoh dan zakat kepada pihak lain yang lebih membutuhkan. TKI di Kecamatan Donomulyo juga berada dalam lingkungan kerukunan beragama yang tinggi

Jika diamati dari aspek budaya, dapat dikatakan bahwa TKI di Kecamatan Donomulyo mempunyai nilai budaya yang masih rendah. Hal ini dapat dilihat dari aspek ber-

Tabel 5. Hubungan Nilai Investasi dengan Lama Kerja

\begin{tabular}{llllll}
\hline $\begin{array}{l}\text { Nilai Investasi/lama } \\
\text { kerja }\end{array}$ & $<5$ Th & 5 & Th -10 & $>10 \mathrm{Th}$ \\
$\mathrm{Th}$ & & & \\
\hline$<50 \mathrm{Jt}$ & 4 & 4 & & \\
$50 \mathrm{Jt}-<150 \mathrm{Jt}$ & 3 & 19 & 1 & 1 \\
$150 \mathrm{jt}-<250 \mathrm{Jt}$ & 7 & 4 & 1 \\
$\geq 250 \mathrm{Jt}$ & & 1 & & 1 \\
\hline
\end{tabular}

Tabel 6. Ringkasan karakterstik Sosial, Budaya dan Ekonomi TKI

\begin{tabular}{llll}
\hline & Sosial & Budaya & Ekonomi \\
\cline { 2 - 4 } N Valid & 270 & 135 & 90 \\
\multicolumn{1}{c}{ Missing } & 0 & 135 & 180 \\
Mean & 2.7407 & 2.3333 & 2.6222 \\
Mode & 3.00 & 2.00 & 3.00 \\
Std. Deviation & .68941 & .70181 & .57236 \\
\hline
\end{tabular}


Karakteristik Mantan Buruh Migran Indonesia... (Sri Wahjuni Latifah)

budaya yang masih kurang, dan mereka merasakan belum adanya sistem kelembagaan dan ketatalaksanaan pemerintah desa yang kurang efisien dan belum tampak adanya kerjasama antar desa untuk meningkatkan nilai bidang kebudayaan.

Jika diamati dari aspek ekonomi nampak bahwa TKI tersebut memiliki karakteristik ekonomi yang tinggi. Mereka berada pada lingkungan usaha yan kondusif, baik usaha perorangan maupun kelompok. Di samping itu mereka pernah mendapat bantuan permodalan dari Bank maupun Koperasi setempat. Bank yang membantu permo- dalan TKI di Kecamatan Domomulyo hanya Bank Rakyat Indonesia saja, sementara bank pemerintah lain belum pernah menyentuh wilayah tersebut.

Jika ditinjau lebih dalam maka karakteristik TKI berdasarkan aspek sosial maka lebih didominasi dari kemampuan mereka dalam memberikan sumbangan kepada orang lain baik dalam bentuk zakat, infaq dan sodaqoh. Mereka juga merasakan adanya lingkungan dalam kerukunan hidup beragama.

Karakteristik TKI berdasarkan dari aspek budaya dapat dikatakan cukup rendah. Hal ini sebenarnya didukung dengan

Tabel 7. Karakteristik Sosial

\begin{tabular}{llllll}
\hline \multirow{2}{*}{ Valid } & & Frequency & Percent & Valid Percent & Cumulative Percent \\
\cline { 2 - 6 } & 1.00 & 7 & 2.6 & 2.6 & 2.6 \\
2.00 & 87 & 32.2 & 32.2 & 34.8 \\
3.00 & 145 & 53.7 & 53.7 & 88.5 \\
4.00 & 31 & 11.5 & 11.5 & 100.0 \\
Total & 270 & 100.0 & 100.0 & \\
\hline
\end{tabular}

Tabel 8. Karakteristik Budaya

\begin{tabular}{llllll}
\hline & & Frequency & Percent & Valid Percent & Cumulative Percent \\
\hline Valid & 1.00 & 15 & 5.6 & 11.1 & 11.1 \\
& 2.00 & 63 & 23.3 & 46.7 & 57.8 \\
& 3.00 & 54 & 20.0 & 40.0 & 97.8 \\
& 4.00 & 3 & 1.1 & 2.2 & 100.0 \\
& Total & 135 & 50.0 & 100.0 & \\
Missing & System & 135 & 50.0 & & \\
Total & & 270 & 100.0 & &
\end{tabular}


Ekonomika-Bisnis Vol. 4 No.1 Bulan Januari Tahun 2013. Hal 85-94

pendapat mereka bahwa desa mereka tinggal belum ada kerjasama dengan daerah lain dalam bidang budaya (seni, olah raga, dan lain-lain).

Karakteristik TKI dari aspek ekonomi dapat dikatakan tinggi. Hal ini dapat diamati dari faktor lingkungan atau iklim usaha yang mendukung karena banyaknya usaha yang berdiri di desa tersebut.Usaha tersebut dimiliki oleh perorangan mapun kelompok. Jenis usaha antara lain: pembuatan kue, toko kelontong, salon rias, warung nasi, dan ada yang minimarket. Dengan demikian dapat dikatakan bahwa lingkungan ekonomi yang kondusif sangat mendukung untuk perkembangan usaha mereka. Hal ini juga merupakan indikator bahwa pelaku usaha di daerah ini tidak tergantung dari bantuan permodalan dari perbankan maupun dari koperasi.

Sebagaimana halnya tentang program CSR untuk semua badan usaha milik negara maka diharapkan perbankan juga melakukan program tersebut baik yang berkaitan dengan lingkungan, ekonomi maupun sosial. Sebagaimana halnya peran perbankan dalam meningkatkan kesejahteraan masyarakat dapat melalui berbagai program.
Berdasarkan hasil penelitian ini dapat dikatakan bahwa mantan buruh migran ini pernah mendapat bantuan permodalan dari Bank sebagai bentuk dana CSR. Bank yang membantu permodalan di Kecamatan Domomulyo hanya Bank Rakyat Indonesia saja, sementara bank pemerintah lain belum pernah menyentuh wilayah tersebut. Selama ini peran perbankan hanya sebatas memberikan bantuan permodalan namun belum ada pembinaan lebih lanjut tentang bagaimana mengelola usaha mereka untuk menjadi lebih baik dengan alasan keterbatasan sumber daya. Dengan demikian dapat dikatakan bahwa belumada metode atau strategi pemberdayaan mantan buruh migran tersebut yang dilakukan oleh perbankan di Malang.

\section{Penutup}

Kecamatan Donomulyo adalah salah satu kecamatan di Kabupaten Malang yang mengirim TKI ke luar negeri dengan jumlah yang cukup banyak. Dari demografinya dapat diketahui bahwa TKI yang berasal dari Kecamatan Donomulyo berumur rata-rata 35,28 tahun. Hal ini indikator bahwa TKI

Tabel 9. Karakteristik Ekonomi

\begin{tabular}{llllll}
\hline & & Frequency & Percent & Valid Percent & Cumulative Percent \\
\hline Valid & 2.00 & 38 & 14.1 & 42.2 & 42.2 \\
& 3.00 & 48 & 17.8 & 53.3 & 95.6 \\
& 4.00 & 4 & 1.5 & 4.4 & 100.0 \\
& Total & 90 & 33.3 & 100.0 & \\
\multirow{2}{*}{ Missing } & System & 180 & 66.7 & & \\
Total & & 270 & 100.0 & &
\end{tabular}


tersebut memiliki usia yang cukup dan demikian memiliki pengalaman yang luas terlihat dari masa kerja yang rata-rata adalah 5,8 tahun.

Jika diamati dari tingkat pendidikan maka TKI dari Kecamatan Donomulyo ini hampir semua memiliki pendidikan yang cukup yaitu tingkat SMA. Tingkat pendidikan SMA merupakan tingkat pendidikan yang cukup untuk mengasah kemapuan bidang lain yang diperlukan seperti Bahasa Asing maupun keahlian masing-masing.

Jika diamati lebih jauh tentang negera tujuan, bahwa TKI dari Kecamatan Donomulyo lebih banyak yang bekerja ke negara Taiwan. Menariknya adalah TKI yang bekerja di negara Taiwan berusia 23 tahun sampai 56 tahun, dengan tingkat pendidikan bervariasi dari SD, SMP maupun SMA/ SMK. Meskipun Negara Taiwan adalah Negara favorit namun belum bisa memberikan penghasilan yang lebih tinggi dibanding negara-negara Korea Selatan, Hongkong, dan Arab Saudi. TKI yang bekerja di Korsel, Hongkong, dan Arab Saudi memiliki nilai investasi yang tinggi yaitu lebih dari 250 (dua ratus lima puluh) juta rupiah, sementara TKI yang bekerja di Taiwan memiliki nilai investasi kurang dari 250 juta rupiah. Bentuk investasi tersebut antara laian adalah rumah, tanah, kendaraan, toko,warung makan, minimarket dan salon.

Berdasarkan hasil analisis data maka dapat dikatakan bahwa mantan buruh migran tersebut memiliki karakteristik yang tinggi baik dari aspek sosial, budaya maupun ekonomi. Ditinjau dari aspek sosial, dapat diukur dari tingkat / rasa aman di daerah tersebut, selalu dilibatkan dalam pengam- bilan keputusan publik pada daerah setempat, mendapatkan pelayanan kesehatan dan menerima bantuan sosial yang cukup dari pemerintah atau instansi lain. Mereka juga dapat melakukan pemberian bantuan sosial seperti infaq, sodaqoh, dan zakat kepada pihak lain yang lebih membutuhkan. TKI di Kecamatan Donomulyo juga berada dalam lingkungan kerukunan beragama yang tinggi.

Jika diamati dari aspek budaya, dapat dikatakan bahwa TKI di Kecamatan Donomulyo mempunyai nilai budaya yang masih rendah. Hal ini dapat dilihat dari aspek berbudaya yang masih kurang, dan mereka merasakan belum adanya sistem kelembagaan dan ketatalaksanaan pemerintah desa yang kurang efisien dan belum tampak adanya kerjasama antar desa untuk meningkatkan nilai bidang kebudayaan.

Sedangkan dari aspek ekonomi nampak bahwa TKI tersebut memiliki karakateristik ekonomi yang tinggi. Mereka berada pada lingkungan usaha yan kondusif, baik usaha perorangan maupun kelompok.

Berkaitan dengan peran perbankan dalam meningkatkan kesejahteraan mantan buruh migran inidapat dikatakan belumefektif. Meskipun mereka pernah mendapat bantuan permodalan dariBank namun belum ada pembinaan lebih lanjut tentang mengelola usaha dengan lebih baik.

Berdasar temuan diatas maka sebaiknya pemerintah setempat bekerja sama dengan lembaga keuangan terkait membentuk kerjasama untuk meningkatkan kesejahteraan mantan buruh migran tersebut dengan mempertimbangkan potensi daerah, skill, dan infrastruktur wilayah tersebut. 
Ekonomika-Bisnis Vol. 4 No.1 Bulan Januari Tahun 2013. Hal 85-94

\section{DAFTAR PUSTAKA}

Almilia, Luciana \& Wijayanto, Dwi. 2007. Pengaruh Environmental Performance dan Environmental Disclosure Terhadap Economic Performance. FEUI.

Alafi, Alif. 2000. Karakteristik Pekerja Migran di Lowokwaru Kota Malang. Skripsi. FEB Universitas Muhammadiyah Malang.

Balabanis, George, Philips, Hugh C., Lyall, Jonathan. 1988. Corporate Social Responsibility \& Economic Performance in the Top British Companies: Are They Linked. European Business Review, Vol. 98 no.1 pp 25-44.

Cormier and Magnan, M. 1999. Corporate Environmental Disclosure Strategies:Determinants, Costs and Benefit. Journal of Accounting, Auditing and Finance, Vol. 14 no. 4 pp. $429-451$.

Cowen S.S., Ferreeri, L.B. and Parker, L. D. 1987. The Impact of Corporate Charactersistic On Social Responsibility Disclosure: A Typolofy and Frequency-Based Analysis" Accounting, Organizations and Society, Vol. 12 No.2. pp. 111- 122.

Elizabeth, Roosganda. 2007. Pemberdayaan Awanita Mendukung Strategi Gender Mainstrame Dalam Kebijakan Pembangunan Pertanian di Pedesaan. Forum Penelitian Agro ekonomi, volume 25 no. 2 Desember 2007: 126135.

Hackston, D and Milne, M.,J. 1996. Some Determinants of Social and environmental Disclosuresin New Zealand
Companies. Accounting, Auditing and Accountability Journal, Vol. 9 No.1 pp.77-108.

Haris, Abdul. 2005. Gelombang Migrasi dan Jaringan Perdagangan manusia. Yogyakarta: Pustaka Belajar.

Karsadi. 2006. Indikator Sosial: Dimensi Kualitatif untuk mengukur Kemajuan dan Keberhasilan Pembangunan Nasional. Makalah Pengembangan Wilayah di Bappeda Prov. Sulawesi Tenggara.

Moekijat. 2006. Asas-Asas Perilaku Organisasi. Bandung: CV. Mandar Maju.

Saleh, Harru Hariawan. 2003. Persaingan Tenaga Kerja Menghadapi Persaingan Global Guna Suksesnya Pembangunan nasional. Kertas Karya Perorangan, Kursus Singkat Lemhanas RI.

Sumodiningrat, G. 1997. Pembangunan Daerah dan Pemberdayaan Masyarakat. Jakarta: Bina Rena Pariwara.

Sumodiningrat, G. 1999. Pemberdayaan masyarakat dan Jaring Pengaman Sosial. Jakarta: Gramedia.

Young, Elspeth. 1984. Pengantar Kependudukan. Yogyakarta: UGM Press. 